\title{
ANALISIS KUALITAS WEBSITE SMK NEGERI 2 SRAGEN DENGAN METODE WEBQUAL 4.0 DAN IPA
}

\author{
Ridwan Aji Pamungkas ${ }^{1)}$, Excel Alfarishi' ${ }^{2}$, Erdian Aditiarna ${ }^{3)}$ \\ , Anang Muklhisin ${ }^{4)}$, Rifda Faticha Alfa Aziza ${ }^{5)}$ \\ 1), 2),3),4),5) Fakultas Ilmu Komputer, Universitas Amikom Yogyakarta \\ Jl. Ring Road Utara, Condong Catur, Depok, Sleman, Yogyakarta 55281 \\ Email: ridwan.pamungkas@students.amikom.ac.id ${ }^{l}$, excel.alfarishi@students.amikom.ac.id ${ }^{2}$, \\ erdian.aditiarna@students.amikom.ac.id ${ }^{3)}$,anang.muklhisin@students.amikom.ac.id ${ }^{4}$, rifdafaticha@amikom.ac.id ${ }^{5)}$
}

\begin{abstract}
Abstrak
Website adalah satu dari sekian banyak media komunikasi yang berisi informasi baik berupa text, suara, gambar, atau video yang dapat diakses secara publik oleh masyarakat luas. Pengukuran dan pengamatan dilakukan untuk mengetahui kualitas suatu website. Dengan melakukan hal tersebut, kita dapat memahami pendapat para pengguna terhadap suatu website. Pelaksanaan penelitian ini menggunakan combined method yaitu metode Webqual sebagai acuan utama dengan indikator kegunaan, kualitas informasi, serta interaksi layanan dan metode Importance Perfomance Analysis(IPA). Target lokasi yang diambil dalam penelitian ini adalah lingkungan SMK NEGERI 2 SRAGEN. Untuk mendapatkan data secara akurat dari pengguna akhir digunakanlah pengumpulan data dengan metode kuisioner. Ruang lingkup obyek yang akan diteliti adalah Siswa SMK Negeri 2 Sragen. Hasil yang akan diperoleh setelah penelitian adalah berkembangnya kegunaan website untuk user yang mengaksesnya. Hal lain seperti tampilan dan layanan yang disediakan menjadi faktor utama terhadap kepuasan pengguna dalam menggunakan website SMK Negeri 2 Sragen.
\end{abstract}

Kata kunci: Usability, Information, Service Interaction Quality, Website.

\section{Pendahuluan}

Dunia teknologi informasi dari waktu ke waktu semakin memperbesar perkembangan penyebaran informasi dalam berbagai media baik media cetak maupun digital dan dalam berbagi bidang salah satunya adalah bidang akademik (Santoso dan Anwar, 2015). Internet adalah salah satu media berbagi informasi dan data yang tidak terikat waktu, jarak dan tempat bagi masyarakat luas. Selain fungsional utama internet sebagai media pertukaran data, internet juga berperan besar dalam pemenuhan kebutuhan masyarakat karena dapat meminimalisir biaya dan akses bebas (Nurhayati, 1998).

Website atau World Wide Web (WWW) menjadi salah satu aspek penting dalam penyediaan informasi secara lengkap dalam berbagai bidang kehidupan yang dapat diakses tanpa Batasan (Monalisa, 2016). Hal tersebutlah yang menjadikan website sebagai media yang dapat dikembangkan baik secara pribadi, organisasi ataupun pihak lain guna pemenuhan kebutuhan, salah satunya di bidang pendidikan akademik seperti halnya yang di implementasikan dalam sistem informasi SMK Negeri 2 Sragen. SMK Negeri 2 Sragen menekankan pemberdayaan media informasi melalui internet untuk mendukung produktivitas pelaksanaan penyeberan informasi seputar sekolah serta publikasi dunia kerja yang dapat diakses ecara publik baik oleh pihak internal atau masyarakat luas. Berdasarkan hal etrsebut, penulis melakukan penilaian kualitas website dengan metode WebQual 4.0 dan Importance Performance Analyst (IPA) (Irawan, 2012).

Webqual 4.0 adalah metode yang digunakan untuk pengukuran kualitas website berdasarkan pengalaman end user yang terdiri dari kegunaan, kualitas informasi, dan interaksi pelayanan (Barnes dan Vidgen, 2003). Ketiga kategori tersebut dijadikan acuan dalam pembuatan kuesioner online untuk menganalisis kualitas website SMK Negeri 2 Sragen. Hasil analisis diharapkan dapat menjadi rekomendasi bagi pihak Sekolah dalam mengembangkan website yang berkualitas sehingga tercapai target pemanfaatannya untuk publik guna memperlancar penyebaran informasi.

\section{Dasar Teori}

\subsection{Webqual 4.0}

Webqual merupakan metode pengembangan dari SERVQUAL yang dikembangkan dengan metode Quality Function Development (QFD) yang bertujuan menilai kualitas suatu website. Pengembangan metode ini sudah dilakukan sejak tahun 1998 dengan versi rilis pertama yaitu versi 1.0 (Barnes dan Vidgen, 2000).

WebQual telah mengalami beberapa iterasi dalam penyusunan kategori dan butir-butir pertanyaannya. Versi terbaru adalah WebQual 4.0 yang menggunakan tiga kategori pengukuran dengan 22 butir pertanyaan. Ketiga kategori tersebut adalah usability, information dan service interaction. Kategori usability berdasar dari kajian mengenai hubungan antara manusia dan komputer dan kajian mengenai kegunaan web, diantaranya mengenai kemudahan navigasi, kecocokan desain dan gambaran yang disampaikan kepada pengguna. Kategori information dikaji berdasarkan kajian sistem informasi 
secara umum. Kategori ini berhubungan terhadap kualitas dari konten website yaitu kepantasan informasi bagi tujuan pengguna, misalnya mengenai akurasi, format dan relevansi dari informasi yang disajikan. Kategori service interaction berhubungan terhadap interaksi layanan yang dirasakan pengguna ketika terlibat secara mendalam dengan website (Barnes dan Vidgen, 2002)

\subsection{Importance Performance Analysis ( IPA )}

Metode IPA dipublikasikan oleh Martilla dan James, metode ini memiliki kemampuan dalam pelayan penyediaan informasi secara tepat dalam penilaian suatu website dengan format yang efisien untuk memaksimal kepuasan pengguna dalam pemanfaatan sebuah website (Megal et al, 2005).

\subsubsection{Analisis Kesesuaian}

Analisis kesesuaian merupakan hasil dari perbandingan antara skor kinerja pelaksanaan (performance) dengan skor kepentingan (importance) untuk mengetahui nilai kepuasan end user terhadap suatu website, dimana $\mathrm{X}$ merupakan tingkat kinerja (perfomance), sedangkan Y merupakan tingkat kepentingan (importance) (Santoso dan Anwar, 2015).

Analisis tingkat kesesuaian akan menentukan skala prioritas yang akan dipakai dalam penanganan dari hasil analisis kuadran. Kriteria penilaian tingkat kesesuaian pengguna yaitu (Santoso dan Anwar, 2015) :

1. Apabila hasil analisa kesesuaian menyatakan > $100 \%$ berarti tingkat kepuasaan user melebihi tingkat harapan yang diinginkan dan user merasa sangat puas.

2. Apabila hasil analisa kesesuaian menyatakan = $100 \%$ berarti tingkat kepuasaan user mencapai tingkat harapan yang diinginkan dan $u$ ser merasa puas.

3. Apabila hasil analisa kesesuaian menyatakan < $100 \%$ berarti tingkat kepuasaan user tidak mencapai tingkat harapan yang diinginkan dan user tidak puas.

\subsubsection{Analisis Kesenjangan (Gap Analyst)}

Analisis kesenjangan adalah pendekatan inovatif dan berguna untuk melakukan penilaian kebutuhan dan untuk mengevaluasi program. Analisis dapat digunakan untuk mengukur perbedaan antara kepuasan pengguna dengan kinerja atau aktual website seperti pada rumus dibawah ini (Santoso dan Anwar, 2015). :

$$
\text { Qi (Gap) }=\text { Perf(i) }-\operatorname{Imp}(\mathbf{i})
$$

Keterangan :

$Q i($ Gap $)=$ Nilai kesenjangan

$\operatorname{Perf}(i)=$ Tingkat kinerja

$\operatorname{Imp}(i)=$ Tingkat kepentingan
Hasil perhitungan gap menunjukkan pengguna merasa puas jika nilai gap bernilai positif dan menunjukkan pengguna merasa tidak puas apabila nilai gap bernilai negative (Santoso dan Anwar, 2015).

\subsubsection{Analisis Kuadran IPA}

Analisis kuadran dalam metode importance performance analysis (IPA) atribut kinerja/kenyataan (performance) digambarkan dengan sumbu-X dan atribut kepentingan/harapan (importance) digambarkan dengan sumbu-Y (Martatilla dan James, 1997).

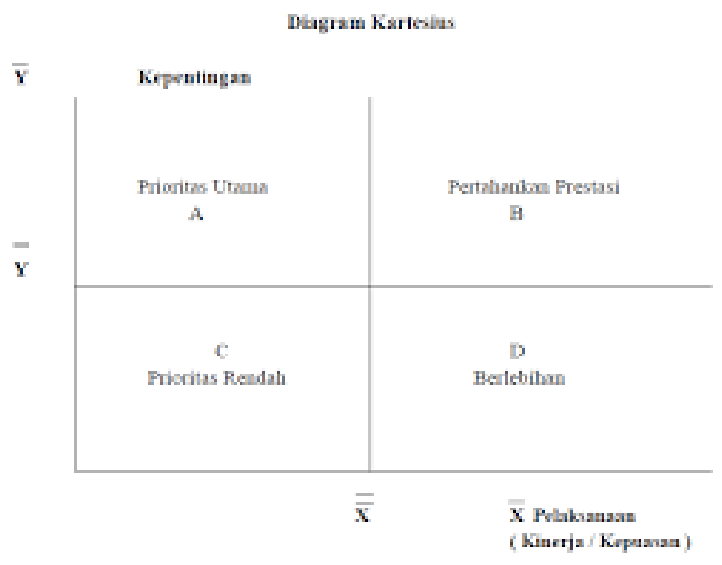

Gambar 1. Diagram Kuadran IPA

Dibawah ini adalah penjelasan dari Diagram Kuadran IPA pada Gambar 1 :

A. Kuadran pertama : "Priorities for Improvement" atribut yang berada dalam lingkup kuadran pertama dengan kinerja rendah namun sangat berpengaruh karena memiliki prioritas kepentingan tinggi sehingga menjadi titik penting dalam poin perbaikan kualitas.

B. Kuadran kedua : "keep ip the good work" atribut yang berada dalam lingkup kuadran kedua dengan kinerja dan prioritas kepentingan yang sama sehingga hanya perlu dipertahankan nilainya untuk menjaga kualitas.

C. Kuadran ketiga : "low priority" atribut yang berada dalam lingkup kuadran kedua dengan kinerja dan prioritas kepentingan yang sama sama rendah sehingga perlu adanya peningkatan pada aspek yang terdapat dalam lingkup kuadran ini.

D. Kuadran keempat : "Possible Overkill" atribut yang berada dalam lingkup kuadran kedua dengan kinerja yang terlalu tinggi dibandingan tingkat kepentingannya sehingga perlunya distribusi pada aspek yang terdapat pada ruang lingkup kuadran lain seperti pada kuadran pertama. 


\section{Metode Penelitian}

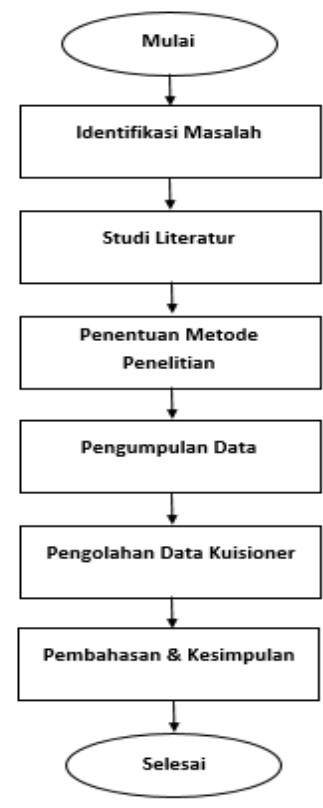

Gambar 2. Langkah Penelitian

\subsection{Identifikasi Masalah}

Identifikasi masalah dilakukan untuk mengetahui permasalahan dengan memalui wawancara serta pengumpulan data dari keluhan Siswa sebagai acuan dari kurang berdaya gunanya website tersebut.

\subsection{Studi Literatur}

Studi literatur dilakukan untuk mendapatkan landasan teori yang sesuai dengan penelitian. Landasan teori didapatkan melalui ebook, jurnal/e-journal, situs website, penelitian sebelumnya, dan dokumen pemerintah.

\subsection{Penentuan Metodologi Peneletian}

Menggunakan webqual 4.0 dan importance and performance analysis (IPA).

\subsection{Pengumpulan Data}

Pengumpulan data dilakukan dengan menggunakan kuesioner secara Online yaitu dengan menggunakan Google Form.

\subsection{Pengelolaan Data}

Metode yang digunakan adalah Webqual 4.0 dan Importance Performace Analyst (IPA).

\subsection{Pembahasan dan Kesimpulan}

Hasil analis dengan Metode yang diguanakan serta Saran yang perlukan guna penelitian selanjutnya dan peningkatan kualitas website.

Penelitian yang dilakukan dimasukkan ke dalam kategori penelitian deskriptif kuantitatif. Variabel-variabel yang digunakan pada penelitian ini adalah berdasarkan pada metode WebQual versi 4.0 berdasarkan penelitian yang dilakukan oleh Barnes dan Vidgen yang terdiri dari usability, information, dan service interaction quality dimana terdiri dari 23 total indikator yang dapat dibedakan menjadi dua jenis, yaitu kualitas yang saat ini dirasakan atau aktual terjadi yang disebut dengan (Performance) dan kualitas yang diharapkan dan dianggap penting untuk dikembangkan yang disebut dengan (Importance).

Proses pengumpulan data yang dilakukan dalam penelitian ini adalah dengan melakukan survei dengan menyebarkan kuesioner kepada para responden. Populasi sampel yang digunakan dalam penelitian ini adalah Siswa SMK Negeri 2 Sragen, tanpa batasan usia dan jenis kelamin.

Jenis pertanyaan yang digunakan dalam kuesioner penelitian ini adalah berupa pertanyaan tertutup (close ended question). Teknik yang digunakan dalam pengambilan sampel yang dilakukan pada penelitian ini adalah judgement sampling yang diukur berdasarkan lima (5) skala mulai dari sangat tidak setuju sampai sangat setuju. Pemilihan skala likert satu sampai lima (15) dipilih untuk mengurangi risiko penyimpangan

Tabel 1 dibawah ini adalah tabel dimana belum dilakukan uji validitas dan realibilitas dalam penentuan penilaian yang digunakan pada penelitian ini. pengambilan keputusan pribadi dan mempunyai kehandalan yang tinggi dengan menghilangkan skala netral atau neutral (Chomeya, 2010). Jumlah sampel yang digunakan adalah sebanyak 120 responden.

Tabel 1. Variabel Penilaian WebQual

\begin{tabular}{|c|c|c|}
\hline Kategori & Indikator & $\begin{array}{c}\text { Kode } \\
\text { variabel }\end{array}$ \\
\hline \multirow{7}{*}{ Usabillity } & Website mudah dipelajari & USA1 \\
\cline { 2 - 3 } & Website mudah dipahami & USA2 \\
\cline { 2 - 3 } & Website mudah bernavigasi & USA3 \\
\cline { 2 - 3 } & Website Tampilan menarik & USA4 \\
\cline { 2 - 3 } & Website meyakinkan bagi anda & USA5 \\
\cline { 2 - 3 } & Sesuai tipe websitenya & USA6 \\
\cline { 2 - 3 } & Memberikan pengalaman positif & USA7 \\
\cline { 2 - 3 } & Warna yang sesuai & USA8 \\
\cline { 2 - 3 } & Font sudah sesuai & USA9 \\
\cline { 2 - 3 } & Alamat website mudah diingat & USA10 \\
\hline
\end{tabular}




\begin{tabular}{|c|c|c|}
\hline \multirow{7}{*}{ Information } & Informasi yang akurat & INF1 \\
\hline & Informasi yang terpercaya & INF2 \\
\hline & Informasi yang tepat waktu & INF3 \\
\hline & Informasi yang relevan & INF4 \\
\hline & $\begin{array}{l}\text { Informasi mudah dalam segi } \\
\text { pemahaman }\end{array}$ & INF5 \\
\hline & $\begin{array}{l}\text { Informasi yang lengkap dan } \\
\text { terperinci }\end{array}$ & INF6 \\
\hline & Format informasi sudah tepat & INF7 \\
\hline \multirow{6}{*}{$\begin{array}{l}\text { Service } \\
\text { Interaction } \\
\text { Quality }\end{array}$} & $\begin{array}{c}\text { Website memiliki rating yang } \\
\text { tinggi }\end{array}$ & SIQ1 \\
\hline & Aman ketika mengakses website & SIQ2 \\
\hline & Aman terhadap informasi pribadi & SIQ3 \\
\hline & Fasilitas personalisasi bagi user & SIQ4 \\
\hline & $\begin{array}{c}\text { Berjalan dengan baik dan } \\
\text { optimal }\end{array}$ & SIQ5 \\
\hline & $\begin{array}{c}\text { Menyediakan kemudahan } \\
\text { masukan atau saran terhadap } \\
\text { pihak sekolah }\end{array}$ & SIQ6 \\
\hline
\end{tabular}

\section{Pembahasan}

Karakteristik dari responden yang terdapat pada penelitian ini menunjukan jumlah pria lebih banyak dibandingkan dengan jumlah wanita, dimana presentase yang diperoleh untuk pria yaitu sebesar $68,8 \%$ dan jumlah presentase wanita sebesar $31,2 \%$.

Berdasarkan segmentasi usia, $62,4 \%$ berada diantara usia 18 - 20 tahun dan 37,6\% berada dibawah usia 21-24 tahun. Pengujian validitas dan realibilitas dari kuesioner yang dilakukan pada penelitian ini mengambil sampel 120 kuesioner. Uji validitas dan realibilitas dilakukan pada indikator kinerja dari website SMK Negeri 2 Sragen (performance).

Analisis ini dilakukan untuk mengetahui tingkat kesenjangan dari data aktual (Performance) dengan tingkat harapan yang diinginkan pengguna (Importance) terhadap obyek website yang diteliti dengan cara menghitung selisi antar tingkat kepentingan (Importance) dengan tingkat kinerja (Performance) secara aktual.

$$
\text { Qi }(\text { Gap })=\operatorname{Perf}(\mathbf{i})-\operatorname{Imp}(\mathbf{i})
$$

Keterangan :

Qi (Gap) = tingkat kesenjangan kualitas

Perf(i) = nilai kualitas yang dirasakan saat ini atau aktual (performance)

Imp(i) = nilai kualitas ideal atau harapan dan penting untuk dikembangkan (importance)

Tingkat kualitas yang baik ditandakan dengan nilai positif atau Qi (gap) $\geq 0$ menunjukkan tingkat kepuasan pengguna bernilai positif atau sudah memenuhi harapan para pengguna dan apabila hasil Qi (gap) $<0$ atau negatif, menunjukkan tingkat kepuasan pengguna bernilai negatif atau belum mencapai harapan. Penjelasan kesenjangan dimensi indikator kualitas diuraikan dalam masing-masing dimensi yaitu usability, information dan service interaction quality.

Tabel 2. Nilai Kesenjangan Indikator Usability

\begin{tabular}{|c|c|c|c|c|}
\hline Var & Indikator & Perf & Imp & $\begin{array}{c}\text { Q(P- } \\
\text { I)/GAP }\end{array}$ \\
\hline USA1 & $\begin{array}{c}\text { Website mudah } \\
\text { dipelajari }\end{array}$ & 2,60 & 3,80 & $-1,20$ \\
\hline USA2 & $\begin{array}{c}\text { Website mudah } \\
\text { dipahami }\end{array}$ & 2,60 & 3,66 & $-1,06$ \\
\hline USA3 & $\begin{array}{c}\text { Website mudah } \\
\text { bernavigasi }\end{array}$ & 2,51 & 3,61 & $-1,10$ \\
\hline USA4 & $\begin{array}{c}\text { Website tampilan } \\
\text { menarik }\end{array}$ & 2,13 & 3,68 & $-1,55$ \\
\hline USA5 & $\begin{array}{c}\text { Website meyakinkan } \\
\text { bagi anda }\end{array}$ & 2,32 & 3,52 & $-1,20$ \\
\hline USA6 & $\begin{array}{c}\text { Sesuai tipe } \\
\text { websitenya }\end{array}$ & 2,43 & 3,61 & $-1,18$ \\
\hline USA7 & $\begin{array}{c}\text { Memberikan } \\
\text { pengalaman positif }\end{array}$ & 2,36 & 3,56 & $-1,20$ \\
\hline USA8 & Warna yang sesuai & 2,17 & 3,60 & $-1,43$ \\
\hline USA9 & Font sudah sesuai & 2,09 & 3,71 & $-1,62$ \\
\hline USA10 & $\begin{array}{c}\text { Alamat website } \\
\text { mudah diingat }\end{array}$ & 2,80 & 3,92 & $-1,12$ \\
\hline & Rata-Rata & 2,40 & 3,67 & $-1,27$ \\
\hline
\end{tabular}

Tabel 2 diatas menunjukan nilai kesenjangan (gap) indikator dalam dimensi usability. Selisih rerata gap menunjukkan angka -(1.27) yang berarti menunjukkan bahwa tingkat kepuasan pengguna terhadap fungsionalitas masih belum tercapai. Indikator yang memiliki gap terbesar adalah pada variabel USA9 yaitu "Font sudah sesuai" dengan selisih gap sebesar -(1.62).

Tabel 3. Nilai Kesenjangan Indikator Information

\begin{tabular}{|c|c|c|c|c|}
\hline Variabel & Indikator & Perf & Imp & $\mathrm{Q}(\mathrm{P}-\mathrm{I}) / \mathrm{GAP}$ \\
\hline INF1 & $\begin{array}{c}\text { Informasi } \\
\text { yang akurat }\end{array}$ & 2,55 & 3,66 & $-1,11$ \\
\hline INF2 & $\begin{array}{c}\text { Informasi } \\
\text { yang } \\
\text { terpecaya }\end{array}$ & 2,69 & 3,73 & $-1,04$ \\
\hline INF3 & $\begin{array}{c}\text { Informasi } \\
\text { yang tepat } \\
\text { waktu }\end{array}$ & 2,39 & 3,51 & $-1,12$ \\
\hline INF4 & $\begin{array}{c}\text { Informasi } \\
\text { yang relevan }\end{array}$ & 2,58 & 3,71 & $-1,13$ \\
\hline $\begin{array}{c}\text { Informasi } \\
\text { mudah dalam } \\
\text { segi } \\
\text { pemahaman }\end{array}$ & 2,56 & 3,61 & $-1,05$ \\
\hline
\end{tabular}




\begin{tabular}{|c|c|c|c|c|} 
INF6 & $\begin{array}{c}\text { Informasi } \\
\text { yang lengkap } \\
\text { dan } \\
\text { terperinci }\end{array}$ & 2,54 & 3,61 & $-1,07$ \\
\hline INF7 & $\begin{array}{c}\text { Format } \\
\text { informasi } \\
\text { sudah tepat }\end{array}$ & 2,45 & 3,55 & $-1,10$ \\
\hline \multicolumn{2}{|c|}{ Rata-Rata } & 2,54 & 3,63 & $-1,09$ \\
\hline
\end{tabular}

Tabel 3 diatas menunjukan nilai kesenjangan (gap) indikator dalam dimensi information. Selisih rerata gap menunjukkan angka -(1.09) yang berarti menunjukkan bahwa tingkat kepuasan pengguna terhadap kualitas informasi masih belum tercapai. Indikator yang memiliki gap terbesar adalah pada variabel INF4 yaitu "Informasi yang relevan" dengan selisih gap sebesar (1.13).

Tabel 4. Nilai Kesenjangan Indikator Service Interaction

\begin{tabular}{|c|c|c|c|c|}
\hline Variabel & Indikator & Perf & Imp & $\mathrm{Q}(\mathrm{P}-\mathrm{I}) / \mathrm{GAP}$ \\
\hline SIQ1 & $\begin{array}{c}\text { Website } \\
\text { memiliki } \\
\text { rating yang } \\
\text { tinggi }\end{array}$ & 2,31 & 3,53 & $-1,22$ \\
\hline SIQ2 & $\begin{array}{c}\text { Aman ketika } \\
\text { mengakses } \\
\text { website }\end{array}$ & 2,40 & 3,61 & $-1,21$ \\
\hline SIQ3 & $\begin{array}{c}\text { Aman } \\
\text { terhadap } \\
\text { informasi } \\
\text { pribadi }\end{array}$ & 2,37 & 3,55 & $-1,18$ \\
\hline SIQ4 & $\begin{array}{c}\text { Fasilitas } \\
\text { personalisasi } \\
\text { bagi user }\end{array}$ & 2,18 & 3,55 & $-1,37$ \\
\hline SIQ5 & $\begin{array}{c}\text { Berjalan } \\
\text { dengan baik } \\
\text { dan optimal }\end{array}$ & 2,27 & 3,55 & $-1,28$ \\
\hline SIQ6 & $\begin{array}{c}\text { Menyediakan } \\
\text { kemudahan } \\
\text { masukan } \\
\text { atau saran } \\
\text { terhadap } \\
\text { pihak } \\
\text { sekolah }\end{array}$ & 2,24 & 3,52 & $-1,28$ \\
\hline \multicolumn{2}{|c|}{ Rata-Rata } & 2,30 & 3,55 & $-1,26$ \\
\hline
\end{tabular}

Tabel 4 diatas menunjukan nilai kesenjangan (gap) indikator dalam dimensi service interaction. Selisih rerata gap menunjukkan angka -(1.26) yang berarti menunjukkan bahwa tingkat kepuasan pengguna terhadap kualitas layanan masih belum tercapai. Indikator yang memiliki gap terbesar adalah pada variabel SIQ4 yaitu "Fasilitas personalisasi bagi user" dengan selisih gap sebesar -(1.37).

Tabel 5. Nilai Kesenjangan Semua Indikator dengan Metode WebQual

\begin{tabular}{|c|c|c|c|}
\hline Indikator & Perf & Imp & $\mathrm{Q}(\mathrm{P}-\mathrm{I}) / \mathrm{GAP}$ \\
\hline
\end{tabular}

\begin{tabular}{|c|c|c|c|} 
Usability & 2,40 & 3,67 & $-1,27$ \\
\hline Information & 2,36 & 3,10 & $-1,09$ \\
\hline $\begin{array}{c}\text { Service Interaction } \\
\text { Quality }\end{array}$ & 2,07 & 3,00 & $-1,26$ \\
\hline Rata-Rata & 2,23 & 3,01 & $-1,21$ \\
\hline
\end{tabular}

Tabel 5 diatas menunjukan nilai kesenjangan atau gap dari ketiga dimensi WEBQUAL. Berdasarkan tabel diatas, secara keseluruhan menunjukkan kinerja (performance) dan kepentingan (importance) memiliki nilai negatif yang menunjukkan angka ( -1.21$)$.

Importance performance analysis (IPA) menjukkan aspek mana saja yang perlu diperbaiki untuk meningkatkan tingkat kualitas suatu website. Proses dalam menentukan kordinat untuk setiap indikator, digunakanlah nilai rata-rata pembobotan indikator dari Tabel 2.

Berikut ini Gambar 3 yang menunjukan posisi indikator dalam grafik matrix IPA, dimana masing-masing dimensi digambarkan dengan masing-masing label.

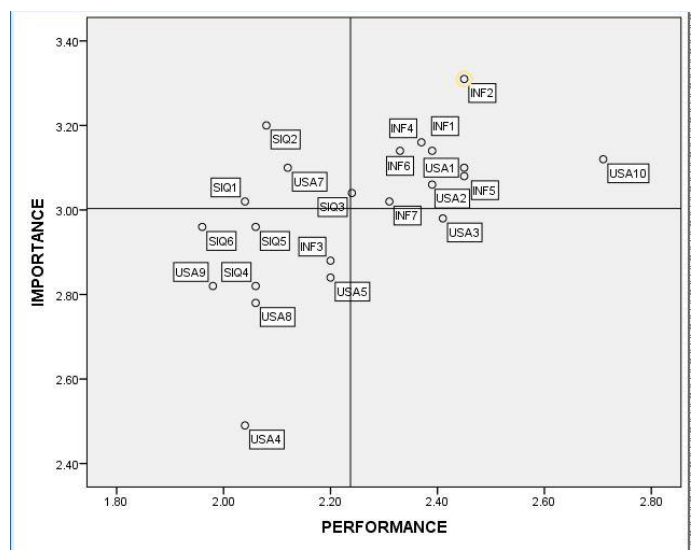

5. Kesimpulan

Berisi berbagai kesimpulan yang di ambil berdasarkan penelitian yang telah dilakukan.Berisi pernyataan singkat tentang hasil yang disarikan dari pembahasan. Saran dapat dituliskan pada bagian paling akhir. Berisi berbagai kesimpulan yang di ambil berdasarkan penelitian yang telah dilakukan.Berisi pernyataan singkat tentang hasil yang disarikan dari pembahasan. Saran dapat dituliskan pada bagian paling akhir.

Berisi berbagai kesimpulan yang di ambil berdasarkan penelitian yang telah dilakukan.Berisi pernyataan singkat tentang hasil yang disarikan dari pembahasan. Saran dapat dituliskan pada bagian paling akhir.

Hasil analisis grafik metode Importance Performance Analyst ( IPA ):

- Kuadran A :

Indikator USA4 yaitu "Website tampilan menarik", USA9 yaitu "Font Sudah Sesuai". Aspek pada kuadran ini perlu menjadi titik berat dalam pengembangan dan peningkatan performa 
oleh SMK Negeri 2 Sragen karena memiki tingkat kepentingan yang tinggi.

- Kuadran B :

Indikator USA1 yaitu "Website mudah dipelajari", USA2 yaitu "Website mudah dipahami", USA10 yaitu "Alamat website mudah diingat", INF1 yaitu "Informasi yang akurat", INF2 yaitu "Informasi yang terpercaya", INF4 yaitu "Informasi yang relevan". Pada kudaran ini memiliki tingkat kepentingan (harapan) yang tinggi dan tingkat kinerja (aktual) pun sudah baik sehingga perlu dipertahankan kualitasnya.

- Kuadran C :

Indikator USA5 yaitu "Website meyakinkan bagi anda", USA7 yaitu "Memberikan pengalaman positif", USA8 yaitu "Warna yang sesuai", INF3 yaitu "Informasi yang tepat waktu", SIQ1 yaitu "Website memiliki rating yang tinggi", SIQ2 yaitu "Aman ketika mengakses website", SIQ4 yaitu "Fasilitas personalisasi bagi user" SIQ5 yaitu "Berjalan dengan baik dan optimal" dan SIQ6 yaitu "Menyediakan kemudahan masukan atau saran terhadap sekolah". Aspek yang berada pada lingkup kuadran sudah dianggap baik karena tingkat kinerja dan performa sudah seimbang sehingga tidak perlu diprioritaskan dalam pengembangannya.

- Kuadran D :

Indikator USA3 yaitu "Website mudah bernavigasi", USA6 yaitu "Sesuai Tipe Websitenya", INF5 yaitu "Informasi mudah dalam segi pemahaman", INF6 yaitu "Informasi yang lengkap dan terperinci", INF7 yaitu "Format informasi sudah tepat". Aspek dalam kuadran ini sudah bernilai positif sehingga bisa dikesampingkan peningkatannya.

\subsection{Saran}

\subsubsection{Saran untuk Pihak Sekolah}

Berdasarkan hasil pembahasan penelitian dan kesimpulan yang telah dipaparkan sebelumnya, berikut beberapa saran yang diharapkan dapat menjadi masukan dan pertimbangan bagi pihak sekolah :

1. Diharapkan pihak SMK Negeri 2 Sragen mampu meningkatkan kualitas informasi (infromaton quality) di websitenya. Baik informasi seputar berita akademik dan penyediaan materi,presetasi, dan bursa kerja.

2. Diharapkan pihak SMK Negeri 2 Sragen dapat mempertahankan bahkan meningkatkan kualitas kegunaan (usability quality) yang sudah kurang baik oleh reponden dalam hal navigasi menu maupun recent kategori yang disajikan, user interface serta layout website yang lebih minimalist.

\subsubsection{Saran bagi Penelitian Selanjutnya}

Berdasarkan hasil pembahasan penelitian dan kesimpulan yang telah dipaparkan sebelumnya, berikut beberapa saran yang diharapkan untuk penelitian selanjutnya:

1. Dikarenakan keterbatasan peneliti, maka diharapkan penelitian selanjutnya mampu memperluas area penelitian dan mencari ruang lingkup dengan populasi yang berbeda dan dengan menggunakan sampel lebih banyak lagi sehingga nantinya dapat diperoleh hasil yang lebih baik.

2. Penelitian yang dilakukan untuk menganalisis kualitas website SMK Negeri 2 Sragen ini menggunakan metode WebQual 4.0. Untuk penelitian selanjutnya dapat menggunakan metode-metode lainnya..

\section{Daftar Pustaka}

SANTOSO \& ANWAR. 2015. Analisis Kualitas Website Menggunakan Metode Webqual dan Importance - Performance Analysis (IPA) Pada Situs Kaskus. National Concference on Information Technology and Technical Engineering (CITEE), 15 September.

NURHATATI. 1998. Analisa Website Puslit Indonesia Dengan Menggunakan WebQual Untuk Pengukuran Kualitas Website.

MONALISA, S. 2016. Analisis Kualitas Layanan Website Terhadap Kepuasan Mahasiswa dengan Penerapan Metode WebQual ( Studi Kasus : UIN Suska Riau ).

IRAWAN. 2012. Evaluasi Kualitas Website Pemerintah Daerah Menggunakan WebQual (Studi Kasus Pada Kabupaten Ogan Ilir).

S.J. BARNES, \& VIDGEN, R. 2003. Measuring Website Quality Improvement : A Case study of the Forum on Strategic Management Knowledge Exchange. Industrial Management and Data Systems. 297-309.

BARNES, S.J., \& R.T. VIDGEN. 2000. Proceedings of the Eighth European Conference on Information Systems, Vol I. 1:298-305.Vienna, July 2000.

BARNES, S. \& VIDGEN, R. 2002. An Integrative Approach to the Assesement of E-Commerce Quality. Journal of Electronic Commerce Research, Vol. 3, No. 3, 2002.

MAGAL, SIMHA, R., LAVENBURG \& NANCY, M. 2005. Using Importance-Performance Analysis to Evaluate E-Business Strategies Among Small Businesses. Proceedings of the $38^{\text {th }}$ Hawaii International Conference on System Science.

CHOMEYA, R. 2010. Quality of Psychology Test Between Likert Scale 5 and 6 Points. Journal of Social Sciences, 6(3):399-403.

MARTATILLA, J.A. \& JAMES, J.C. 1977. Importance Performance Analysis. 